The Vulnerability of Judges in Contemporary Africa: Alarming Trends Author(s): Tabeth Masengu

Source: Africa Today, Vol. 63, No. 4 (Summer 2017), pp. 3-19

Published by: Indiana University Press

Stable URL: http://www.jstor.org/stable/10.2979/africatoday.63.4.01

Accessed: 18-07-2017 08:33 UTC

JSTOR is a not-for-profit service that helps scholars, researchers, and students discover, use, and build upon a wide range of content in a trusted digital archive. We use information technology and tools to increase productivity and facilitate new forms of scholarship. For more information about JSTOR, please contact support@jstor.org.

Your use of the JSTOR archive indicates your acceptance of the Terms \& Conditions of Use, available at http://about.jstor.org/terms

Indiana University Press is collaborating with JSTOR to digitize, preserve and extend access to Africa Today 


\section{Academics and lawyers}

need to be more vigilant

in ensuring that judges can

operate in environments

in which they can exercise

their functions without

fear, favor, or prejudice. 


\title{
The Vulnerability of Judges in Contemporary Africa: Alarming Trends Tabeth Masengu
}

\begin{abstract}
The judicialization of politics has been described as one of the most significant phenomena of late twentieth-and early twenty-first-century government. The courts have more judicial muscle than they did centuries ago, but it would be a mistake to assume that with more power has come more protection. This article discusses judicial independence by highlighting some concerning instances of judicial interference that have occurred in sub-Saharan Africa since 2010. In my discussion of these threats, I highlight that the executive is not the only avenue by which interference in the judiciary occurs. I conclude with suggestions of ways in which judges as social actors can mitigate undue influence and present a stronger judiciary.
\end{abstract}

In September 2015, local investigative journalist Anas Aremeyaw Anas publicized his documentary on corruption in the Ghanaian judiciary. He documented twelve High Court judges, twenty-two other judges, and 140 other court officials accepting bribes, effectively debunking the widely held belief that judges are above reproach. ${ }^{1}$ The implications of the documentary were damning, not only for the judges and court officials involved, but for the judiciary as a whole. The judiciary is often viewed as the shield to protect a country's citizenry in an era in which some leaders continue to use authoritarian methods to extend their stay in power or to crush dissenting voices. ${ }^{2}$ As a consequence of this, a focus has been on what the courts and judges can do for citizens, with insufficient consideration of what happens when the guardians of our courts need guarding, too.

Former Lesotho Chief Justice M. L. Lehohla, in a speech at the Southern African Chief Justices Forum, stated, "most pernicious of the challenges facing judiciaries in Africa today is that of undue interference or influence in one form or another," and despite the outlawing of undue interference with the judiciary in most constitutions, African executives had a growing tendency to exert political leverage or control over the judiciary (2010:3). Similarly, at the same forum, Zimbabwean Chief Justice Godfrey Chidyasiku 
pointed out that challenges to judicial independence were likelier to take a subtler form than their precursors; the pressures, he continued, "if more subtle, are nonetheless insidious" (2010:10).

The alteration of the political landscape in Africa in the early 1990s has played a significant role in creating environments where these pressures have become common. Since the early 1990s, we have witnessed the concomitant emergence of courts endowed with powers of judicial review and the creation of a robust bill of rights in a number of African countries (Ellet 2015:6). This emergence of judicial power has often led to contestation with other organs of state, especially the executive. Instances in which judges or their positions have been threatened in overt and sometimes covert ways have increased in the last decade. This has led to the need to discuss the vulnerability of judges in contemporary Africa, especially as the courts become bolder and more willing to exercise their judicial muscle.

This article examines the issue of judicial interference, with an emphasis on a few key incidents that have been identified in the sub-Saharan region since 2010. I commence with a brief discussion of judicial independence and the judicialization of politics. I then examine the issue of judicial interference by drawing attention to some concerning incidents, emanating from within the judiciary, as well as from the executive. I draw heavily from the works of Peter VonDoepp, Rachel Ellet, and Jennifer Widner, who have conducted research on the African continent. By discussing topical examples of judicial interference, I provide evidence that supports these scholars' theories. Finally, I suggest three practical ways for judges to strengthen their own independence and that of the judiciary as a whole.

\section{Judicial Independence and the Role of the Courts}

Judicial independence and judicial accountability are not mutually exclusive, but accountability does not negate the importance of independence. Article 2 of Siracusa's Draft Principles on the Independence of the Judiciary states that judicial independence means:

\footnotetext{
(a) That every judge is free to decide matters before him in accordance with his assessment of the facts and his understanding of the law without any improper influences, inducements, or pressures, direct or indirect, from any quarter or for any reason, and

(b) That the Judiciary is independent of the Executive and Legislature, and has jurisdiction, directly or by way of review. (UN Committee of Experts 1981).
}

Despite numerous guidelines on judicial independence, ${ }^{3}$ contention continues to exist because the role of the courts has evolved over time, and judges find themselves adjudicating matters that are seemingly political, as opposed 
to just commercial and criminal. This has led to what is commonly referred to as the judicialization of politics.

The judicialization of politics is the ever-accelerating reliance on courts and judicial means for addressing core moral predicaments, public policy questions, and political controversies, as courts have delved into megapolitics-political controversies that define the boundaries of the collective or cut through the heart of entire nations (Hirschl 2008:5). Matters described as megapolitics include determining electoral process outcomes, deciding on executive prerogatives, and ruling on the legitimacy of regime changes, matters of transitional justice, and cases in which the nation is defined via the courts (Hirschl 2008:7-13). The judicialization of politics is not a new phenomenon; it is a feature of established democracies, such as the United States, as well as countries that have undergone transition, such as those in Latin America (Domingo 2004:107). The degree and extent to which courts resolve political and social disputes vary from country to country: some countries in Southeast Asia, such as Thailand, Indonesia, and Malaysia, have witnessed an increase in the role of the courts in defining the political landscape, while others have not (Dressel 2010).

Courts on the African continent have made a fair contribution to the judicialization of megapolitics in the last two decades, despite not being situated in countries considered established democracies. Electoral process outcomes have been a common arena for judicialization. Courts have played a critical role in postelection disputes in Uganda in 2006, Ghana in 2013, Kenya in 2013, and Malawi in 2014 (Ellett 2015:6). Recent examples include Burundi's Constitutional Court allowing Pierre Nkuruzinza, the incumbent president, to run for a third term in $2015^{4}$ and the Zambian Constitutional Court's dismissal of an election petition to annul the August 2016 election results. ${ }^{5}$

The courts are now active adjudicators of human and socioeconomic rights cases-matters of megapolitics. ${ }^{6}$ Before the year 2000, few cases focused on gender discrimination and women's personal rights. ${ }^{7}$ Since then, numerous instances of judicial activism have occurred, including the groundbreaking South African Constitutional Court decision regarding the rollout of antiretrovirals to HIV-positive mothers in 2002 and the recognition of the right of HIV-positive women to decide on sterilization in Namibia in 2012. ${ }^{8}$ In Botswana, the courts confirmed the unconstitutionality of discriminatory customary law inheritance in 2013. In Uganda in 2015, a court found the payment of a bride-price refund to be unconstitutional. ${ }^{9}$

\section{Judicial Interference: What Lies Beneath}

Judicial interference is not exclusive to Africa, or to developing countries generally. Judiciaries in Canada, the United States, and even the United Kingdom also grapple with confrontational politics and public disdain, on varying levels. ${ }^{10}$ From an African perspective, Kwasi Prempeh, a renowned 
constitutionalist, posits that historically, after the achievement of independence in many African countries, "the idea of judicial independence-of a judicial function separate and apart from the executive and legislative functions and of judges free from routine political control-would be among the first casualties of the illiberal ideologies" (Prempeh 2006). He explains that the colonial legal order had been conceived primarily for the purposes of dominance rather than legitimacy; thus, judicial independence was never a priority (Prempeh 2005). This context explains some of the difficulties still experienced in judiciaries today, but there is more to judicial interference than meets the eye.

Does judicial interference occur because the courts have become politicized and thus need to be reined in? Or do the courts descend into uncharted legal waters in response to the executive's moves to disempower them? Hirshl believes:

\begin{abstract}
An authentic, "bottom up" judicialization is more likely to occur when judicial institutions are perceived by social movements, interest groups, and political activists as more reputable, impartial, and effective decision-making bodies than other bureaucracy-heavy government institutions or biased majoritarian decision-making arenas. An all-encompassing judicialization of politics is, ceteris paribus, less likely to occur in a polity featuring a unified, assertive political system that is capable of restraining the judiciary. (Hirschl 2006:745)
\end{abstract}

The bottom-up judicialization that Hirschl describes relies on a judiciary that is empowered and influential and does not shy away from presiding over matters of megapolitics as part of the job. Such boldness leads people often to consider judges to be wilful architects of the countermajoritarian dilemma.

In contrast, judicialization may occur because a government seeks to centralize its control, reduce its accountability to the courts, or curtail citizens' rights (Sunkin 1994:126). Ironically, what ensues in these cases is that the courts' reaction to government restraint results in a move away from formal constitutional systems of accountability, in favor of more informal, less accessible, and less accountable methods of decision making. The knee-jerk reaction from government to limit how far the court can spread its tentacles serves only to galvanize judges to have an indelible impact, even in situations where the legislature may be better placed to do so.

Whether judicialization arises before judicial interference or vice versa, the struggle for power is clear-a struggle of which judicial independence is but one component. Other aspects of judicial power are the ability to make binding judgments, the ability to have these judgements enforced, and the presence of discretionary powers (Gillespie 2007:849). Then there is the struggle for political power, with the adjudication of megapolitics as the locus of the public's respect. The impact of legal decisions can legitimate 
judiciaries in people's eyes. For instance, public support for the Thai Constitutional Court grew immensely after the court's decision to annul the April 2006 elections, stripping Thaksin Shinawatra of his role as prime minister. The status of the South African judiciary was enhanced exponentially in 2016, when the Constitutional Court held that the president should pay back a portion of public money spent on security upgrades at his homestead. ${ }^{11}$ Sometimes, this increase in respect for the judiciary can mean a decrease in support for the executive.

When these struggles for power arise, judicial interference starts to appear in various forms. Six broad categories of judicial interference in southern Africa have been identified. These are general institutional assaults, personal manipulation, remuneration manipulation, personal attacks, patronage and personal linkages, and communication (VonDoepp and Ellet 2011:153). In these instances, the executive and/or its allies use different means to convey similar messages when they disapprove of court decisions or believe that an impending judicial outcome will not be in their favor. Institutional assaults often take the form of legislative overrides of controversial rulings, and political tinkering with judicial appointment and tenure procedures to ensure the appointment of "compliant" judges and/or to block the appointment of "undesirable" ones (Hirschl 2006).

A commonly cited example of legislative override is the Indian case of Mohammed Ahmed Khan v. Shah Bano Begum and Others, ${ }^{12}$ where a decision by the Supreme Court of India regarding the maintenance of a Muslim spouse by her husband was virtually overturned by parliament. ${ }^{13}$ Overriding controversial rulings is fairly uncommon. It was possible in Shah Bano because of the backlash from Muslims, who perceived the decision as interfering with their identity. If the politics of the country are such that there exists a powerful-both political and financial—catalyst to push the government, such as seen in Shah Bano or in The Wik Peoples v. Queensland case, ${ }^{14}$ a decision can be overruled; however, this tactic shows the executive's hand, exposing him or her to pressure from the opposition and civil society organizations.

Tinkering with judicial appointments as a form of institutional assault can be executed in a less risky manner. Take the ousting of former Chief Justice Anthony Gubbay in March 2001 by President Robert Mugabe and his ruling ZANUPF party. That action was sold on the need to indigenize the judiciary, and Gubbay was replaced with the outgoing Chief Justice Chidyasiku (Blair 2001). In Kenya, President Uhuru Kenyatta waited a year to appoint fourteen judges who had been recommended by the Judicial Service Commission because he allegedly did not like the names on the list. ${ }^{15}$ The delay was not illegal, as the power to appoint is vested in the president alone; therefore, unless tampering with the list or irrationality could have been proven, the president was technically well within in his rights. For weeding out undesirable judges, subtle methods such as these are safer for governments and can be used in a manner that will bring less scrutiny than overriding a court decision. 
Finally, "undue" pressure depends in part on the political climate and culture of the jurisdiction in question, the tier of the judiciary under consideration, and the leadership of the judiciary (Patterson 2006). In agreement with this point, one judge stated that judicial independence sometimes depends on the political climate, because countries with a democratic deficit do not care much about judicial independence and find it an irritation. ${ }^{16}$ Simply put, if a political party is in power today, yet cannot guarantee that it will stay in power when the next presidential election comes about, it is less likely to try to abuse the judiciary. The experiences of judiciaries in Uganda, the Gambia, Swaziland, and Zimbabwe (primarily between 2001 and 2004), where judges and lawyers have suffered from informal interference, seem to support this view. These examples have a common factor: the same political party, president, or monarch had or has been at the helm for at least two decades.

\section{Executive Interference: Zambia, The Gambia, and Burundi}

When tension exists between the roles of the judiciary and the executive, sometimes the case in question has nothing to do with megapolitics, as has occurred in Zambia. On 30 May 2012, judges Nigel Mutuna and Charles Kajimanga of the High Court, and judge Phillip Musonda of the Supreme Court, received a written letter of suspension from President Michael Sata, with no reasons provided. The president held a press conference on the same day, stating that by the powers vested in him under articles 98(2) (3) and (5) of the Zambian Constitution, he would appoint a tribunal to investigate allegations of the said judges' incompetence and misbehavior. The judges countered that at no point had any such allegations been made known to them or to the Judicial Complaints Authority, as prescribed under the Judicial Code of Conduct Act No. 13 of 1999. Judges Mutuna and Kajimanga sought an ex parte order for leave to apply for judicial review and a stay of the president's decision-which was granted on 14 May by the High Court.

The attorney general appealed to the Supreme Court after a bid to discharge the leave failed, and it was at that stage that Judge Musonda joined the proceedings. The Supreme Court of Appeal, by a majority of four to three, found that the president had unfettered powers in exercising the powers vested in him under articles 98(2)(3) and (5). ${ }^{17}$ The court, even though it found that the president had not usurped the powers of the Judicial Complaints Authority or those of the Chief Justice, advised that "considering the circumstances of the matter, the tribunal should not proceed."18 This decision was widely criticized, ${ }^{19}$ with renowned academic Professor Ndulo stating that until this decision, he had believed that African judiciaries had emerged from the period of powerlessness and marginalization at the hands of "imperial presidents"; he stated that article 98 had not been drafted to become the conduit of executive influence over the judiciary, and removing 
judges from the bench on spurious grounds was the greatest threat to judicial independence (Ndulo 2016:3).

Judge Musonda resigned in 2013, and judges Mutuna and Kajimanga were reinstated in 2015. The former is now a judge of the Supreme Court, and the latter has since stated that the trigger for his and Judge Mutuna's suspension had been a judgment delivered by the latter in Development Bank of Zambia v. Post Newspapers Ltd, JCN Holdings Ltd and Mutembo Nchito. Kajimanga's "crime" had been allocating the case to Judge Mutuna, whose decision went against the defendants-who had close connections to President Sata (Kajimanga 2016:3). In an interview with an anonymous judge of a superior court in Zambia, I was informed that the defendants were not only close to the president, but financially and politically powerful, having had ties to Sata before he had taken office. ${ }^{20}$ The brave action by Mutuna in the high-stakes court case confirms the view that judges in Zambia still retain some capacity for disrupting the political agendas of those in power (VonDoepp 2009:16).

It is striking that the above Supreme Court decision was handed down when Chibesakunda was still acting as chief justice, despite having reached retirement age. Parliament had declined to ratify her appointment as a permanent chief justice, but Sata was willing to bend the rules to appoint her. Thus, her decision in the Kajimanga case was considered by some as a move to curry favor with Sata and ensure that she would be permanently appointed as chief justice. Her actions may therefore be remembered for giving the impression that she was interested more in cementing her position than in shoring up the independence of the judiciary.

The experience of the Zambian judges, however, pales in comparison to that of Judge Mable Agyemang, now of the Ghanaian High Court. Judge Agyemang was appointed chief justice of The Gambia in August 2013, with an impressive judicial track record, having served as an appellate court judge for the Commonwealth Secretariat. After just six months in office, she fled the country in the middle of the night, having been informed that she had been removed from her post without prior notice or a disciplinary hearing. President Yahya Jammeh has publicly stated that she was taking orders from a hostile country (Ocloo 2012), but she believes that it is because she was a perceived to be a "human-rights judge." It was feared that she would release political prisoners condemned to death, as she had previously released opposition detainees in 2002. ${ }^{21}$ Before this incident, the International Bar Association (2006) had expressed concern that over time, the government's actions had undermined judicial independence and the rule of law, and it noted that in the preceding few years, one judge's contract had not been renewed, one had been forced to resign, and one had been forcibly removed; in all these instances, each judge had given judgments that were not in the government's favor. ${ }^{22}$ In 2013 alone, three chief justices were dismissed, with Ali Nawaz Chawhan, Agyemang's successor, removed after only a year in office /Ocloo 2012). The use of foreign judges is a curious aspect of the Gambian situation. Nigerian national Amelia Izuako, a former Gambian judge, commenting on 
the fact that the Court of Appeal had no permanent judges and so foreign judges from the High Court would sit as ad-hoc judges, emphasizes that from her experience, this pattern did not ensure confidence in the system, and that to have an indigenous bench (what she calls a Gambianized higher bench), there needed to be greater institutional security, financial security, and security of tenure, so that it would be worthwhile for Gambian judges (Izuako 2009:99-100).

In May 2017, six judges from Nigeria and Sierra Leone had been scheduled to sit on the Court of Appeal to hear Jammeh's petition disputing the December 2016 presidential election results (Kamara and Ahotonu 2016). Persistent mediation from the Economic Community of West African States ultimately led Jammeh to relinquish power, eliminating the need for the court to hear the matter. ${ }^{23}$ Appointing foreign judges to hear a case of such great significance gave the impression that Jammeh did not trust the Gambian judges. From the perspective of a Gambian judge, it may have been safer not to be involved in a highly political petition that would have had serious ramifications, whichever way it was decided. Nonetheless, if Jammeh did not trust Gambian judges to deliver a decision in his favor, did he consider foreign judges to be more compliant? As contract judges, foreign personnel would not necessarily have been vested in the judiciary and country as a whole. They may not have had a legitimate reason to decide impartially, knowing that they would not reap the effects of the decision. Still, foreign judges like Agyemang, Izuako, and others have exhibited the type of independence that had them dismissed. Thus, perhaps it was not just about foreign judges, but about getting the "right" type of foreign judge.

Finally, I return to the Burundi Constitutional Court's decision that backed President Nkurunziza's bid for a third term. The judgment was signed by five Constitutional Court justices and appeared to be unanimous. Constitutional Court Vice President Sylvere Nimpagaritse later revealed that the court had been forced to validate the decision (Al Jazeera 2016). He told the media that the justices had initially found Nkurunziza ineligible to run for another term. After that decision, the Constitutional Court justices all received threatening phone calls. ${ }^{24}$ The remaining justices then changed their decision to favor Nkurunziza because, according to Nimpagaritse, "if we did not give the third term a green light, we were going to be in trouble" (Al Jazeera 2016). Considering the continued deaths and human-rights violations that have occurred since that decision, the case provides a clear illustration of how interference in judicial independence has ripple effects throughout society.

\section{The Chief Justice as the Antagonist: The Cases of Swaziland and Botswana}

When a judiciary as an institution experiences external attacks on its integrity, it can withstand attempts of interference from external influences if 
it has a dependable chief justice. A strong and able chief justice can personify the independence of the judiciary and exemplify that independence in the conduct of judicial proceedings in his or her court (Commonwealth Magistrates and Judges Association 2014). The role of the chief justice has four key aspects: intellectual leadership, managing judicial matters, administrative leadership, and representing and defending the judiciary where needed (Leakey 2012). An example of a chief justice giving effect to the last-mentioned aspect occurred in the South African judiciary on 8 July 2015, when the judiciary held an unprecedented press conference with twenty-seven of the country's top judges, led by Chief Justice Mogoeng. The judiciary sought to respond to what it called "repeated and unfounded criticism of the judiciary" (Grootes 2015). ${ }^{25}$ The chief justice believed it was necessary to reaffirm the judiciary's independence and protect his judges, notwithstanding criticism from the ruling party.

In Judge Thomas Masuku's case in Swaziland, however, it was Chief Justice Michael Ramodebedi who proved to be the persecutor of his own judge, thereby taking an unprecedented primary role in dismantling, subverting, and abrogating the rule of law and the independence of the judiciary in Swaziland (Masuku 2016). Masuku, who had been on the Swazi bench since 1999, was suspended on 28 June 2011 in a manner shrouded with suspicion. He was accused of insulting the Swazi king. The end of his judicial career in Swaziland was largely attributed to the chief justice at the time, who was both the judge and juror in the case (International Commission for Jurists 2016). Masuku subsequently filed a complaint with the African Commission on Human and Peoples' Rights, ${ }^{26}$ and has since been appointed a judge in Namibia. ${ }^{27}$

Chief justices must ensure that lower levels of the judiciary respect admonishments not to allow partisan interference in legal proceedings (Widner 1999:183), but when chief justices themselves are the conduit for partisan interference, the foundations of the judiciary are compromised. Ramodebedi is said to have failed to protect and defend the institutional independence of the judiciary, and played a reprehensible role in undermining the institutional independence of the judiciary and that of individual judges (International Commission for Jurists 2016:5). He is reported to have issued a practice directive, abrogating fair process in allocating cases and allowed himself to intervene in allocating sensitive and political cases. ${ }^{28}$ Thereafter, the government won all its cases in the Supreme Court, prompting the head of government to celebrate openly-by hosting a lunch in honor of those responsible for his unprecedented victories (Masuku 2016:2). Ramodebedi himself would face impeachment charges and be removed from office in July 2015.

As chief justice, one is not only the head of the judiciary in a legal sense, but also a manager. Malawian Chief Justice Andrew Nyirenda has stated that being a chief justice is an immense responsibility, and one has to draw a delicate balance as a leader because "one is dealing with colleagues who have equal knowledge and experience, some even more experienced than 
you. ${ }^{\prime 29}$ Where judicial independence is increasing, chief justices often pursue several tactics simultaneously to strengthen the judiciary's position (Widner 1999:81). These include altering executive perspectives when necessary, improving the effectiveness of the judiciary, and building constituencies. These tactics do not appear to have been followed in Botswana.

At the 2015 Annual Judicial Conference in Mahalapye, Botswana, some judges voiced concern that the judiciary was in need of additional resources for the continuous training of judicial officers and support staff, and they recommended that judicial leadership should seek resources for training. ${ }^{30}$ Aggrieved by the suggestion, Chief Justice Maruping Dibotelo accused some of the judges of misappropriating housing allowances erroneously paid to them; he publicly claimed that they were thieves, and vowed to destroy their careers (Garekwe 2016:20). Not long thereafter, Judge Key Dingake of the Gaborone High Court and judges Modiri Letsididi, Mercy Garekwe, and J. Ranier Busang of the Labotse High Court all received letters dated 10 August 2015. The letters were from the chief justice, written in his capacity as chairman of the Judicial Service Commission. They stated that the government payroll section had erroneously been paying them housing allowances for a considerable period of time, without the government's consent, and that the matter was being reported to the police for investigation. The judges denied the allegation of criminal conduct, expressing concern at Dibotelo's public statement to destroy their careers, and requesting that he resign or face the possibility of impeachment. ${ }^{31}$

On 26 August, the four judges received letters of suspension from President Ian Khama, informing them that a tribunal had been appointed to decide whether they were fit to hold office. ${ }^{32}$ The suspension led to a public outcry and criticism from numerous bodies. ${ }^{33}$ A statement from the Law Society of Botswana expressed concern at the chief justice's conduct in interfering with other judges; it "resolved that the latest actions of the Chief Justice clearly lend credence to the call for him to either resign or face impeachment." ${ }^{\prime \prime 4}$ The president rejected a request to lift the suspensions, and an urgent application to have them set aside was turned down by the High Court. ${ }^{35}$ Later, a request to have an impartial tribunal composed of judges who had no ties to the Botswanan judiciary was turned down. A subsequent audit report found that other judges-who had not been charged-had received the allowances erroneously, and the department had continually failed to deduct the overpayment from their salaries, as requested by Dingake and another judge. ${ }^{36}$ The suspension of the judges has since been lifted as of late March 2017 and the tribunal has been disbanded. Yet, the incident remains a stark reminder of just how precarious the position of a judge can be. ${ }^{37}$

Admirably, the response from the Law Society and the public showed that Botswana is not an environment in which judicial interference will go unchallenged. In addition, while members of the bar in the region had previously only irregularly raised their voices on behalf of the judiciary, the bar in Botswana appears to have done so when it mattered most. The bar in Swaziland was also vocal when Masuku was ousted, and so, too, in Zambia 
during the saga of Kajimanga and others and when Chibesakunda was being primed for the role of permanent chief justice. ${ }^{38}$

Chief justices must strike a delicate balance, in which they lead the judiciary as an institution, but do not influence individual judges in an inappropriate way through their leadership (Leakey 2012). This delicate balance is one that must remain at the fore of all judicial operations if a judiciary is to avoid a repeat of the above examples.

\section{Judges as Social Actors: What Now?}

Some view judges through their preferences and patterns of decision making, but others view them as creative protagonists in the process of judicial development (VonDoepp 2009:27). Thus, they are more than just actors wielding influential power through decision making, but are rather individualistic agencies for the creation of a better, richer, and more respected judicial system. With the judicialization of politics, an appreciation of judges as protectors of their own autonomy is necessary, and the first step toward this is acknowledging judges as social and political actors (Trochev and Ellet 2014:68). The idea that judges are social and political actors is supported by instances where African judges have played a central role in initiating bids for greater independence (Widner 1999). There is evidence of this in the numerous chapters of the International Association of Women Judges scattered over the region. These chapters have issued statements concerning the inadequate legislation on violence against women and human trafficking-which would be considered the domain of the legislature. ${ }^{39}$ Here, they have entered the fray outside the courtroom to use their collective agency to prompt the development of necessary legislation as a means to curb social ills.

Another aspect of judicial autonomy concerns judges' behavior outside the courthouse, as judges' informal relationships with other social actors shape the nature and boundaries of judicial autonomy, affecting the social construction of judicial power (Trochev and Ellet 2014:68). There is evidence of this in the career of Francis Nyalili, a chief justice of Tanzania who notably traversed the political, judicial, and public space. He is said to have provided a window for "understanding the interactions between judges, politicians, and the public throughout the African region and the consequences for judicial independence and the rule of law" (Widner 2001:68). Other judges have taken to conducting lectures in law schools or writing in academic journals, and in the process have earned academic admiration and support. Those who have written legal articles for newspapers or hosted talk shows, like South African Judge Dennis Davis, ${ }^{40}$ have brought the law to the people and earned the respect of the public outside the courtroom. The consequence of such activities is that, when judicial interference occurs, these stakeholders feel they have an interest in defending the judiciary's independence; therefore, they offer an informal strategy of survival for judges seeking to protect their autonomy and maintain their influence (Trochev and Ellet 2014). 
Ultimately, how can the recognition of judges as social actors and the social construction of judicial power assist with judicial independence? I suggest that judicial education is but one solution to this. This education can take various forms, such as judge's forums organized by external bodies, which merely facilitate conversations on topical issues, such as the use of foreign law in judgments and the rights of sexual minorities. ${ }^{41}$ To avoid any perception of undue influence by the organizers, it is crucial that such forums be chaired by sitting or retired judges. The education could also take the form of continued legal education that orients new judges and provides practical tips for judgment writing. ${ }^{42}$ Judicial education not only reminds judges of their responsibilities, but provides the means by which judges can learn from colleagues and be forewarned and forearmed to face likely sources of undue influence. This will assist them in defending their independence.

Furthermore, the creation of regional networks among judges is important. Judges have started to form regional communities that have served as advocates for denouncing acts of interference. During the sagas of judges Masuku and Agyemang, judges from the region not only provided emotional support, but lent their voices to the cause..$^{43}$ The mentioned incidents were a precursor of the creation of the African Judges and Jurists' Forum, which seeks to enhance the rule of law, good governance, and economic growth through standard setting, judicial and legal reform support, and rule-of-lawrelated capacity-development initiatives. ${ }^{44}$ Its creation shows that African judges are no longer satisfied with being members only of international bodies, such as the Commonwealth Magistrates and Judges Association. They want a creation of their own, where they can have an authentic, indigenous voice on matters that are particularly contentious in the region, even if they may be happening elsewhere. The creation of such bodies may harness the power of the collective and send a message that any undue interference with one judge interferes with the independence of all.

While the Botswana judges were on suspension, their plight continued to be a topic of debate and discussion at regional forums. It galvanized not only the bar in Botswana, but also regional bodies, such as the Southern African Development Community Lawyers Association (SADCLA). These stakeholders were concerned not only for their respective judiciaries, but for other judges, whom they recognized as being pivotal to the greater aim of rich judicial development. Judges without allies are more vulnerable. Once the wider community gets involved, be it the bar, magistrates, academics, or civil-society organizations, it makes it that much harder for executives and chief justices to do as they please. By creating and maintaining relationships with stakeholders who are not part of the judiciary, judges in the region can engender a sense of ownership in the judiciary and build a second line of defense for themselves. 


\section{Conclusion}

The focus of this article is to draw attention to instances of judicial interference as a way of highlighting the challenges involved in maintaining judicial independence. Judicial independence does not exist so judges can "go rogue" and undermine the rule of law: it exists to enable judges to deliver impartial justice free from external pressures, for the benefit of the community (Izuako 2009:94). Academics and lawyers need to be more vigilant in ensuring that judges can operate in environments in which they can exercise their functions without fear, favor, or prejudice. The examples cited in this article are just the tip of the iceberg, and as courts grow bolder, more such instances are yet to come:

[a]s legal reasoning develops, judges do not become immune from extraneous political and moral ideas, but rather the particular form in which political or moral ideas enter the law is determined by the law's sense of its own purpose and usefulness. (Gillespie 2007)

The usefulness and purpose of the law will be determined by those who make judicial decisions and those who have to abide by them. The shifting of goal posts is inevitable, and whether it is to the judges' detriment or benefit will depend on how well they navigate their roles as social actors. It will also depend on whether the constructions of social power can be built in a manner that protects judges' autonomy. The more allies are aware of the challenges faced by judges and are willing to defend judiciaries, the stronger the judiciary will be.

\section{ACKNOWLEDGMENTS}

I would like to express my appreciation to the two anonymous reviewers solicited by Africa Today. My gratitude extends to associate professors Josephine Dawuni and Rachel Ellet, of Howard University and Beloit College respectively, for reviewing an earlier draft of this article, and Lauren Gildenhuys for her editorial assistance.

NOTES

1. Twenty lower court judges have since been dismissed, while some High Court judges are facing impeachment.

2. The tenures of presidents Yoweri Museveni and Robert Mugabe and Burundi's Pierre Nkurunziza are an example.

3. Among others, article 26 of the African Charter on Human and Peoples' Rights of 1981. 
4. For a translation of the Burundi case, see http://www.ihrda.org/wp-content/uploads/2015/05 /Judgment-of-Burundi-Constitutional-Court-ENGLISH-Translation.pdf.

5. Filed by the opposition party, the United National Democratic Party.

6. As described by Hirschl in his five categories of megapolitics.

7. Before 2000, Unity Dow v. Attorney-General 1991 Blr 233 (HC) in Botswana, Longwe v. Intercontinental Hotel 1992/HP/765 (HC) in Zambia, and the South African case of Whitehead v. Woolworths (Pty) Ltd (C 122/98) [1999] ZALC 82 (28 May 1999).

8. Minister of Health and Others v. Treatment Action Campaign and Others (No 1) (CCT9/02) [2002] ZACC 16, LM and Others v. Government of the Republic of Namibia (I 1603/2008, I 3518/2008, I 3007/2008) [2012] NAHC 211.

9. Mmusi and Others v. Ramantele and Another (MAHLB-000836-10) [2012] BWHC 1 and Mifumi (U) Ltd \& 12 Others v. Attorney General, Kenneth Kakuru (Constitutional Petition No.12 of 2007) [2010] UGCC 2 (26 March 2010).

10. Beloff 2000:153.

11. Economic Freedom Fighters v. Speaker of the National Assembly and Others and Democratic Alliance v. Speaker of the National Assembly and Others

12. (1985 SCR (3) 844).

13. India's parliament bowed to massive political pressure by conservative Muslims and overruled the Indian Supreme Court's decision by passing the Muslim Women's (Protection of Rights of Divorce) Act.

14. (1996) 141 ALR 129. In Wik, the government bowed to pressure from the mining and agricultural sector and introduced amendments to the Native Title Act that overrode Wik.

15. Interview with a member of the Kenyan Law Society who was interviewed for a Democratic Governance and Rights Unit project on 10 August 2016.

16. Discussion with a judge based in the region.

17. Appeal No. 088/2012 [2013] ZMSC 38 (9 May 2013); SCZ/8/185/2012.

18. The tribunal was to be headed by Lovemore Chikopa, a Malawian judge.

19. See Elias Munshya wa Munshya, "With Forked Tongues: Why Chibesakunda's Majority Ruling in Attorney-General v. Mutuna \& Others Is Flawed," https://eliasmunshya.org/2013/07/01 /with-forked-tongues-why-chibesakundas-majority-ruling-in-attorney-general-v-mutuna -others-is-flawed.

20. Anonymous interview conducted at the court residence on 2 December 2016.

21. Minutes of the SADC Judges Forum, hosted by the DGRU on 8-10 May 2015, in Windhoek, Namibia.

22. Nigerian Judge Izuako, former Chief Justice Brobbey, and Gambian jurist Justice Jallow.

23. Jammeh eventually agreed to step down on 20 January 2017 after mediation efforts that lasted two months.

24. He is currently exiled in Rwanda.

25. The judiciary had received a barrage of criticism following a decision that the failure to take steps to arrest and/or detain Omar Hassan Ahmad Al Bashir, President of the Republic of Sudan, was inconsistent with the Constitution of the Republic of South Africa, 1996. See Southern African Litigation Centre v. Minister of Justice \& Constitutional Development and Others 2016 (1) SACR 161 (GP).

26. Communication 444/13-Justice Thomas Masuku (represented by Lawyers for Human Rights Swaziland) v. Swaziland.

27. The commission's decision is still pending. 
28. The report can be found on the ICJ website.

29. Stated at the SADC Judges Forum held at Mangochi Beach Resort, Malawi, in September 2016.

30. Information contained in a letter written to the Judicial Service Commission by twelve judges, dated 17 August 2015, which is in the author's possession.

31. Letter to the Chief Justice, dated 12 August, which is in the author's possession.

32. Presidential letters addressed to all judges, which states that their suspension would commence on 1 September 2015, which are in the author's possession.

33. Amnesty International at https://www.amnesty.org/en/latest/news/2015/10/botswana -suspension-of-judges-potentially-threatens-freedom-of-expression-and-judicial -independence/ and the SADC Lawyers Association at http://citizen.co.za/807102/lawyers -call-for-return-of-four-suspended-botswana-judges.

34. The chief justice had offered "amnesty" to eight other judges who had petitioned for his removal. They were offered amnesty if they retracted their statements, and as of September 2015, three had done so.

35. Decision by Justice Tebogo Tau.

36. An electronic copy of the report by the Department of Administrative Justice is in the author's possession.

37. Judge Mercy Garekwe will resume work at the end of June 2017, with the others doing so later in the year when the terms of the judges acting in their stead ends..

38. See statements from the SADC Lawyers Association and other media reports from respective bars.

39. The Nigerian, Tanzanian, and Kenyan chapters of the association in particular are very active.

40. Davis's show, Judge for Yourself, aired weekly, critically analyzes South Africa's myriad political and socioeconomic issues.

41. The DGRU, based at the University of Cape Town, hosts such forums annually, in South Africa and in other countries in the region.

42. DGRU and the International Commission of Jurists have partnered to form the Judicial Institute for Africa, chaired by current and former judges, which runs twice a year at no cost to participants.

43. Both judges expressed their gratitude for this.

44. Founded 23 November 2012.

\section{REFERENCES CITED}

Aljazeera. 2016. Burundi Court "Forced" to Validate Leader's Third Term. http://www.aljazeera.com /news/2015/05/150508061821607.html.

Beloff, Michael J. 2000. Neither Cloistered nor Virtuous? Judges and Their Independence in the New Millennium. The Denning Law Journal 15.

Blair, David. 2001. Zimbabwe Chief Justice Agrees to Stand Down. The Telegraph. http://www.telegraph .co.uk/news/worldnews/europe/1324928/Zimbabwe-Chief-Justice-agrees-to-stand-down .html.

Chidyasiku, Godfrey. 2010. Emerging Threats to Judicial Independence in Africa. Keynote Address at the ICJ Emerging Threats to Judicial Independence in Africa Roundtable, Harare, Zimbabwe, April 28-29. 
Commonwealth Magistrates and Judges Association. 2014. Conference Report: Independence of the Judiciary. Livingstone, Zambia. http://www.cmja.org/downloads/confreports/ConferenceReport Zambia.pdf.

Domingo, Pilar. 2004. Judicialization of Politics or Politics of the Judiciary. Democratization 11(1):104-26.

Dressel, Bjorn. 2010. Judicialization of Politics or Politicization of the Judiciary? Considerations from Recent Events in Thailand. The Pacific Review 23(5):671-91.

Ellett, Rachel. 2015. Judicial Independence under the APRM : From Rhetoric to Reality. Occasional Papers, 212. file:///H:/Conference Attendance 2016/LSA2016 conference/Articles/Judicial IndependenceundertheAPRM.pdf.

Garekwe, Mercy. 2016. Country Study on Current Threats to Judicial Independence-Botswana. Paper presented at the ICJ Emerging Threats to Judicial Independence in Africa Roundtable, Harare, Zimbabwe, April 28-29.

Gillespie, John. 2007. Rethinking the Role of Judicial Independence in Socialist-Transforming East Asia. International and Comparative Law Quarterly 56(4):837-69.

Grootes, Stephen. 2015. When Judges of the Land Said Enough. Daily Maverick. http://www.daily maverick.co.za/article/2015-07-08-when-judges-of-the-land-said-enough-to-the-anc/\#.Vv4 $-2 \mathrm{vl} 96 \mathrm{M} 8$.

Hirschl, Ran. 2006. The New Constitutionalism and the Judicialization of Pure Politics Worldwide. Fordham Law Review 75:722-54.

2008. The Judicialization of Mega-Politics and the Rise of Political Courts. Annual Review of Political Science 11:93-118.

International Bar Association. 2006. Under Pressure:A Report on the Rule of Law in the Gambia. Access. International Commission for Jurists. 2016. Justice Locked Out: Swaziland's Rule of Law. Crisis International Fact-Finding Mission Report. Switzerland.

Izuako, Nkemdilim Amelia. 2009. Judicial Independence and the Gambian Judiciary. West Africa Review 14(14):90-102.

Kajimanga, Charles. 2016. Country Study on Current Threats to Judicial Independence in the RegionZambia. Paper presented at the ICJ Emerging Threats to Judicial Independence in Africa Roundtable, Harare, Zimbabwe, April 28-29.

Kamara, Ken, and Tala Ahotonu. 2016. Gambian Election Crisis: Jammeh Appoints Six Foreign Judges to Supreme Court to Hear His Petition as President-Elect Barrow Prepares for Inauguration. African Courier. http://www.theafricancourier.de/africa/gambian-election-crisis-jammeh -appoints-six-foreign-judges-to-supreme-court-to-hear-his-petition.

Leakey, Kyela. 2012. The Role of the Chief Justice in Commonwealth Africa: A Comparative Study of South Africa, Ghana, and Kenya. PhD diss., University of London.

Lehohla, M. L. 2010. Sustaining the Independence of the Judiciary. Johannesburg: South African Chief Justice's Forum Conference.

Masuku, Thomas. 2016. Country Study on Current Threats to Judicial Independence in the Region-The Case of Swaziland. Paper presented at the ICJ Emerging Threats to Judicial Independence in Africa Roundtable, Harare, Zimbabwe, April 28-29.

Ndulo, Muna. 2016. Professor Muna Ndulo on Judicial Independence and Supreme Court's Decision in Matter of Three Judge[s]. Zambian Watchdog. http://www.zambiawatchdog.com /professor-muna-ndulo-on-judicial-independence-and-supreme-courts-decision-in-matter -of-three-judges.

Ocloo, Della. 2012. Justice Agyemang Safe in Ghana. http://www.graphic.com.gh/news/general -news/19467-justice-mabel-agyemang-safe-in-ghana.html. 
Patterson, Alan. 2006. The Scottish Judicial Appointments Board: New Wine in Old Bottles. In Appointing Judges in an Age of Judicial Power: Critical Perspectives from around the World, edited by Kate Mallesonand Peter Russell, 13-38. Toronto: University of Toronto Press.

Prempeh, H. Kwasi. 2005. Marbury in Africa Judicial Review and the Challenges to Constitutionalisim. Tulane Law Review 80(4):1239-1323.

- 2006. African Judges, in Their Own Cause: Reconstituting Independent Courts in Contemporary Africa. International Journal of Constitutional Law 4(3):592-605.

Sunkin, Maurice. 1994. Judicialization of Politics in the United Kingdom. International Political Science Review 15(2):125-33. http://www.jstor.org/stable/1601560.

Trochev, Alexei, and Rachel Ellet. 2014. Judges and Their Allies: Rethinking Judicial Autonomy through the Prism of Off-Bench Resistance. Journal of Law and Courts Spring: 1-25.

UN Committee of Experts. 1981. Draft Principles on the Independence of The Judiciary (Siracusa Principles). Siracusa. http://www.cristidanilet.ro/docs/SiracusaPrinciples.pdf.

VonDoepp, Peter. 2009. Judicial Politics in New Democracies: Cases from Southern Africa. Boulder, Colo.: Lynne Rienner.

__ and Rachel Ellet. 2011. Reworking Strategic Models of Executive-Judicial Relations: Insights from New African Democracies. Comparative Politics 43(2):147-65.

Widner, Jennifer. 1999. Building Judicial Independence in Common-Law Africa. In The Self Restraining State: Power and Accountability in New Democracies, edited by Marc F. Schedler, Andreas Diamon, and Larry Plattner, 177-94. Boulder, Colo.: Lynne Rienner.

-2001. Building the Rule of Law: Francis Nyalali and the Road to Judicial Independence in Africa. New York: W. W. Norton \& Company.

TABETH L. MASENGU is a senior researcher at the Democratic Governance and Rights Unit at the University of Cape Town. She is also a PhD fellow affiliated with the Human Rights Centre, Department of European, Public, and International Law, Ghent University. Her research interests and areas of publication include gender and judging, women's rights, and interactions between women's rights and constitutionalism. Email: tabeth.masengu@ uct.ac.za 